\title{
Evaluation of Microbial Degradation of Crude Oil in a Polluted Tropical Soil
}

\author{
Ekpobari Neebee \\ Department of Environmental Management, \\ School of Environmental Science, \\ Federal University of Technology Owerri,
}

Nigeria

\begin{abstract}
This research is aimed at determining the growth and capacity of microorganisms to degrade crude oil following biostimulation with NPK fertilizer and sawdust amendment. The contaminated soil was treated simultaneously with the nutrient amendment in treatments $A, B, C, D, E, F, G, H$ and I and the population of microorganisms involved in the degradation of TPH monitored. Optimum conditions for effective degradation of the contaminant were determined and the kinetics of the process evaluated. Physicochemical and biological parameters like soil pH, texture, total petroleum hydrocarbon (TPH), total nitrogen, total phosphorus, hydrocarbon-degrading bacteria (HDB), and hydrocarbon-degrading fungi $(H D F)$ in the native, control and treated soils were analyzed using standard analytical method and procedures. The HDB/HDF population measured for TPH degradation at intervals established the efficiency and kinetics of the bioremediation process. However, HDB growth rate in the treatments were between 0.1840 and 0.1931. The utilization of nitrogen and phosphorus by microorganisms was between $81.5 \%$ and $92.8 \%$. TPH degradation in the treatments was between $98.14 \%$ and $99.05 \%$ and degradation rates between -0.0419 day-1 and -0.0479 day-1. However, optimum treatment was achieved in 105 days with an efficiency of $99.05 \%$ in the first-order kinetics at degradation constant of -0.0479 day-1, degradation half-life of 14.47 days, the microbial growth rate of 0.1921 day-1, and biomass doubling time; 3.61 days. Arousal of the population of indigenous microorganisms at the study site through the application of nutrients and a permeable medium resulted in massive biotransformation of the pollutants to non-toxic environmentally friendly forms.
\end{abstract}

Key words: Hydrocarbon, Indigenous, Microorganism, Degradation, Bio-transformation, Remediation.

\subsection{INTRODUCTION}

Pollution by crude oil is a persistent occurrence where it is exploited, transported or refined. Aside the associated social, sanitary and economic impacts [1], agricultural productivity and monetary value of the affected site decrease. Oil spills essentially occur along pipelines, from vessels and at the well heads. Permeability of the affected soil and viscosity of the impacting crude oil determines the extent of spread on land. However, the degree of success of biodegradation of spilt oil is predicated on the growth and population of hydrocarbon-degrading microorganisms [2].

The concomitant adverse alteration of the physical, chemical and biological properties of land, water and air [3] by crude oil constitutes a threat to living organisms and humans $[4,5]$. By these effects, crude oil is classified as priority environmental pollutant by the United States Environmental Protection Agency (USEPA) and calls for sustainable technologies to mitigate the associated risks. Enhancement of the capacity of the autochthonous microorganisms to degrade the pollutant without adverse ecological effect is the most veritable option.

Biostimulation and bioaugmentation are familiar strategies for enhancing effective microbial degradation of hydrocarbon in contaminated soil by different authors: [6, 7, 8, 9 and 10]. While biostimulation amends the polluted soil with organic or inorganic nutrients to promote endogenous microbial growth for enhanced biodegradation, bioaugmentation introduces cultured hydrocarbon degrading microorganisms into the polluted soil. Overall, the 
population of indigenous microorganisms is boosted for biochemical metabolism and mineralisation of pollutants through physiological reactions into nontoxic form, catalysed by the microorganism [11]. Applied either separately or jointly $[12,13], 55 \%$ decrease in TPH concentration in a field aged petroleum contaminated soil by nitrogen amendment at a sub artic site at temperatures between $4.7^{\circ} \mathrm{C}$ and $10{ }^{\circ} \mathrm{C}$ was achieved by [7]. [10] Administered a mix of NPK fertiliser and Saw dust and elicited a 0.192/day growth rate of soil microorganism resulting in $99.05 \%$ restoration of the crude oil polluted soil. This reduced the risk to the natural and social environment at the affected site [14].

The rate of degradation varies with microbial population, hydrocarbon, physicochemical and hydrological condition of the subsurface environment [15]. The characteristic hydrophobicity of hydrocarbon and its binding to soil components apparently hampers its bioavailability. In addition to increase in population, evolving microbial colonies possess adaptive chromosomes for hydrocarbon utilisation which facilitated the enzyme mediated mechanism of oxidation, catalysed by oxygenase and peroxidases [16]. By bio-transformation into less harmful substances, the mobility and migration, spread and risk of toxicity of the pollutant is eliminated [17].

Each microbial group has particular metabolic capability for substrates or their intermediate compounds [18]. A consortium of such groups synergizes in a metabolic relationship, complementing each other's role for perfect hydrocarbon clean-up [19]. The resultant non-toxic carbon dioxide, water, harmless inorganic salts as well as cell biomass (mainly protein) renders microbial degradation more sustainable.

Fungal colonies are not left out in the biodegradation process. They function by adherence to the soil matrix and thrive even at low nutrient concentrations, low humidity and acidic conditions as a result of their non-specific enzyme system [20]. However, the synergy between fungi and bacteria manifest in fungi cleaving the aromatic rings and bacteria degrading the resulting intermediate products [20]. [2] Noted that hydrocarbon degraders constitute less than $1 \%$ of the microbial community in unpolluted environments and about $10 \%$ in oil-polluted ecosystems. Application of optimum amount of essential nutrients facilitates the population bloom of the organisms. However, bacterial population are more abundant then the fungi counterpart. Basically, these microorganisms secret biosurfactants (Rhamnolipid) to stimulate desorption of hydrocarbon for degradation. This secretion lowers the interfacial tension, solubilize hydrophobic organic compounds, and aid transfer from the soil-sorbed phase to the pseudo-aqueous phase [18].

The chemistry of biodegradation is summarised in the equation where the microorganisms mediated utilisation of organic compounds under aerobic condition produce nontoxic carbon dioxide, water and heat energy. The heat energy sustains the temperature of the medium for optimum microbial activity.

$$
\text { Biodegradation: } \mathrm{C}_{x} \mathrm{H}_{y} \mathrm{O}_{z}+\mathrm{O}_{2} \stackrel{\text { Microbes }}{\longrightarrow} \mathrm{CO}_{2}+\mathrm{H}_{2} \mathrm{O}+\text { Heat }
$$

Aerobic and heterotrophic bacteria which use carbon source for cell growth, sustenance of metabolic functions and as electron donor are the most active in biodegradation [21]. Molecular oxygen however, constitutes the terminal electron acceptor for aerobic degradation and yields the most energy, catalyzed by the enzyme oxygenase. Basically, nitrogen and phosphorus as essential nutrients for bacterial cell growth influence microbial proliferation. Heterotrophic and hydrocarbon degrading Bacteria and fungi have the capacity to transform natural and synthetic organic pollutants into sources of energy and non-toxic compounds in their metabolic or growth processes.

The blend of NPK fertiliser and Sawdust in biostimulation of crude oil polluted soil offers both nutrient and enhanced permeability to the soil for easy flow of the nutrient, air and water while the surfaces of the sawdust are conducive for growth and adsorption by the microbes. Operational cost and time is reduced and the efficiency of the remediation process improves without adverse effect on soil functionality and resources management. 
This study evaluates the growth of indigenous hydrocarbon degrading microorganisms in a polluted soil following nutrient application and the resultant degradation of the pollutant. It identifies the optimum treatment in the light of crude oil degradation efficiency and the microbial growth rate in the medium.

\subsection{MATERIALS AND METHODS}

This research was executed on a flat land located at Iriebe in Obio-Akpor local government area of Rivers state, Nigeria, close to a flow station operated by Shell Petroleum Development Company (SPDC). It is located on Latitude; $4^{\circ} 53^{`} 20.35^{\prime \prime}$ and longitude; $7^{\circ} 06^{`} 29.80^{\prime \prime}$ and an elevation of 76 feet above sea level.

It was conducted in the field using analytical experimental design in a completely randomized block fitted into a $3^{2}$ full factorial design with NPK $\left(\mathrm{X}_{1}\right)$ and Saw dust $\left(\mathrm{X}_{2}\right)$ as the independent variables. A $250 \mathrm{~m}^{2}$ area of the study area was measured. Nine cells of 1.0 square meter each (A, B, C, D, E, F, G, H, and I) in two replicates along with a control cell (J) were established and adequately ridged from each other to forestall pollutant migration. The physical properties, (soil moisture content, particle size distribution and temperature), chemical properties (TPH, PAH, soil pH total nitrogen, total phosphorus and total organic carbon) and biological properties (HDB and HDF) untreated soil were determined for baseline information. Oil spill was then simulated in all twenty-seven cells using five (5) litres of crude oil to each. The control cell (J) was likewise polluted.

Batches of three cells were treated consecutively with $1 \mathrm{~kg}, 2 \mathrm{~kg}$ and $3 \mathrm{~kg}$ of a blended N.P.K fertilizer (61:15:15) followed simultaneously with $0.5 \mathrm{~kg}, 1 \mathrm{~kg}$ and $2 \mathrm{~kg}$ of fine saw dust according to the experimental design. The fertiliser and saw dust were thoroughly mixed with the soil to a homogenous matrix. Samples were collected from each cell for analysis. The cells were re-tilled after sampling for aeration and homogeneity. This tilling also helped to mix and optimize contact among the microorganisms, hydrocarbon, moisture and nutrients for maximum oil degradation. The residual concentration of TPH, PAH, Nitrate, Phosphate, $\mathrm{HDB}, \mathrm{HDF}, \mathrm{pH}$ and moisture were analysed periodically to establish the trend of microbial growth and hydrocarbon degradation.

\subsection{Physicochemical analysis of the soil}

Soil $\mathrm{pH}$ was determined electrometrically with $\mathrm{HACH}$ multi-parameter $\mathrm{pH}$ meter and particle size analysis done using Bouyoucos hydrometer method, BS 1377 (1990) of the British Standards Institution and ASTM-D423/D-424-54T (1975) of the American Society for Testing and Materials. Moisture content was determined by gravimetric method (ASTM D2216-66) while total organic carbon was determined by the Walkley and Black method adopting high temperature combustion method (APHA 5310B). Total Nitrogen was determined using the Kjedhal oxidation method with HACH digesdahl digestion apparatus/the peroxide method. However, total Phosphorus was determined by ascorbic acid-phosphomolybdate method and measured with HACH UV spectrophotometer. Total petroleum hydrocarbon (TPH) was extracted according to USEPA 3550C, concentrated and analysed using gas chromatography fitted with flame ionisation detection (GC/FID) - USEPA 8270. Polycyclic Aromatic Hydrocarbon (PAH) was likewise analysed by gas chromatography fitted with mass Spectrometry (GC/MS) - USEPA 8270.

\subsection{Microbiological Analysis of hydrocarbon degrading Bacteria and Fungi}

The indigenous soil microorganisms with hydrocarbon degrading abilities were isolated, identified and their microbial population determined before and within intervals of the treatment process. Bacteria were enumerated using vapour phase transfer technique adopting spread plate method in a mineral salt medium - APHA 9215C. Cell morphology and gram staining reaction was employed for identification and characterization of bacterial isolates. Fungal isolates were also enumerated using vapour phase transfer technique adopting spread plate method - APHA 9610C but antibiotics were added to suppress the growth of bacteria. Fungi identification was by morphological characteristics and microscopic examination. 


\subsection{RESULTS AND DISCUSSION}

The soil was slightly acidic, has some residual TPH and low concentration of nitrogen and phosphorus. The texture was loamy with few microbial colonies of bacteria count $2.10 \times 10^{2} \mathrm{cfu} / \mathrm{g}$ and fungi $3.7 \times 10^{1} \mathrm{cfu} / \mathrm{g}$. However, these baseline characteristics changed in response to pollution by crude oil with significant impact on the physical, chemical and biological properties as shown in Table 1.

\begin{tabular}{|c|c|c|}
\hline Parameter & Baseline & Day 0 of Pollution \\
\hline TPH (mg/kg) & 215.2 & 11000.22 \\
\hline PAH (mg/kg) & 3.15 & 28.16 \\
\hline HUB (cfu/g) & 210 & 214.0 \\
\hline HUF (cfu/g) & 37 & 59.0 \\
\hline Nitrogen $(\mathrm{mg} / \mathrm{kg})$ & 9.1 & 9.49 \\
\hline Phosphorus (mg/kg) & 49 & 49.0 \\
\hline TOC $(\%)$ & 1.38 & 4.44 \\
\hline $\mathrm{pH}$ & 5.28 & \\
\hline Moist. Content (\%) & 4.62 & \\
\hline Temperature (oC) & 27 & \\
\hline
\end{tabular}

Source: Field survey

Crude oil pollution raised the TPH and PAH concentrations in the polluted soil to $11000 \mathrm{mg} / \mathrm{kg}$ and $28 \mathrm{mg} / \mathrm{kg}$ respectively. Microbial population became more significant after acclimatization. Prior to treatment, organic carbon concentration overwhelmed the baseline concentrations of nitrogen and phosphorus.

\subsection{Crude oil degradation following nutrient and microbes' interaction}

Several colonies of hydrocarbon degrading bacteria and fungi predominant in the crude oil polluted soil before and during treatment were identified as presented in Table 2. The native soil had hydrocarbon degrading microbial colonies indigenous to the soil in a few numbers. However, the presence of crude oil elicited the growth of suitable colonies which grew luxuriantly enhanced by the nutrients for crude oil degradation. It could be noted from the table that Mycobacterium spp., and Corynebacterium spp., as well as Acremonium spp., and Fusarium spp., showed presence following NPK-saw dust amendment.

Table 2: Predominant hydrocarbon degrading microorganisms in the treated and untreated soil

\begin{tabular}{|c|c|c|}
\hline $\begin{array}{c}\text { Soil } \\
\text { Description }\end{array}$ & $\begin{array}{l}\text { Predominant Bacterial } \\
\text { colonies }\end{array}$ & $\begin{array}{l}\text { Predominant } \\
\text { Fungi colonies }\end{array}$ \\
\hline Native Soil & $\begin{array}{l}\text { Arthrobacter spp., } \\
\text { Bacillus spp., } \\
\text { Flavobacterium spp., } \\
\text { Micrococcus spp. }\end{array}$ & $\begin{array}{l}\text { Cladosporium spp., } \\
\text { Penicillium spp., } \\
\text { Aspergillus spp., }\end{array}$ \\
\hline Treated Soil & $\begin{array}{l}\text { Arthrobacter spp., } \\
\text { Bacillus spp., } \\
\text { Micrococcus spp., } \\
\text { Flavobacterium spp., } \\
\text { Norcadia spp., }\end{array}$ & $\begin{array}{l}\text { Cladosporium spp., } \\
\text { Penicillium spp., } \\
\text { Aspergillus spp., } \\
\text { Trichoderma spp., } \\
\text { Candida spp., }\end{array}$ \\
\hline
\end{tabular}




\begin{tabular}{|c|l|l|}
\hline & $\begin{array}{l}\text { Rhodococcus spp., } \\
\text { Pseudomonas spp., } \\
\text { Alcaligens spp., } \\
\text { Mycobacterium spp., } \\
\text { Corynebacterium spp., }\end{array}$ & $\begin{array}{l}\text { Acremonium spp., } \\
\text { Fusarium spp., }\end{array}$ \\
\hline $\begin{array}{c}\text { Untreated soil } \\
\text { (Control) }\end{array}$ & $\begin{array}{l}\text { Bacillus spp., } \\
\text { Arthrobacter spp., }\end{array}$ & Cladosporium spp., \\
& $\begin{array}{c}\text { Flavobacterium spp., } \\
\text { Micrococcus spp., }\end{array}$ & Aspergillus spp., \\
& Candida spp., \\
& Alcaligens spp., & Trichoderma spp. \\
& Rhodococcus spp., & \\
& Pseudomonas spp. & \\
\hline
\end{tabular}

The Mean bacterial population, growth rate, nutrient utilisation, crude oil degradation rate and soil restoration efficiency resulting from the treatments using NPK fertiliser and sawdust amendment are presented in Table 3. It was observed that microbial population growth increased with increase in concentration of the fertilizer due to the amount of nutrient available for utilisation. Within each NPK fertiliser level, the treatment response increased as sawdust concentration increased to $1 \mathrm{~kg}$ but regressed with further increase to $2 \mathrm{~kg}$ as expressed by the degradation rate $(\mathrm{K})$. This may be due to high water retention that suffocated the process, having exceeded the optimum concentration of saw dust.

Table 3: Microbial degradation characteristics, nutrient utilisation and restoration efficiency of treatments with NPK fertiliser and saw dust amendment

\begin{tabular}{|c|c|c|c|c|c|c|c|c|c|}
\hline Treatments & $\begin{array}{c}\text { NPK } \\
: \\
\text { Sawdust } \\
\text { (Kg }\end{array}$ & $\begin{array}{c}\text { Mean HDB } \\
(\mathrm{CFU} / \mathrm{g})\end{array}$ & $\begin{array}{c}\boldsymbol{\mu} \\
\left(\mathrm{day}^{-1}\right)\end{array}$ & $\begin{array}{c}\mathbf{T}_{\mathbf{d}} \\
\text { (days) }\end{array}$ & $\begin{array}{c}\mathbf{K}_{\mathbf{d}} \\
\left(\mathrm{day}^{-1}\right)\end{array}$ & $\begin{array}{c}\mathbf{N} \\
\text { utilised } \\
(\%)\end{array}$ & $\begin{array}{c}\mathbf{P} \\
\text { utilised } \\
(\%)\end{array}$ & $\mathbf{K}\left(\mathrm{day}^{-1}\right)$ & $\begin{array}{c}\text { Restoration } \\
\text { Efficiency (\%) }\end{array}$ \\
\hline A & $1: 0.5$ & $4.18 \times 10^{5}$ & 0.1837 & 3.77 & -0.1570 & 84.6 & 77.0 & -0.0442 & 98.61 \\
\hline B & $1: 1$ & $4.56 \times 10^{5}$ & 0.1841 & 3.77 & -0.1692 & 85.1 & 81.5 & -0.0452 & 98.70 \\
\hline $\mathrm{C}$ & $1: 2$ & $4.55 \times 10^{5}$ & 0.1844 & 3.76 & -0.1706 & 82.2 & 83.8 & -0.0420 & 98.23 \\
\hline D & $2: 0.5$ & $5.50 \times 10^{5}$ & 0.1911 & 3.63 & -0.1420 & 89.6 & 88.3 & -0.0441 & 98.52 \\
\hline $\mathbf{E}$ & $2: 1$ & $8.33 \times 10^{5}$ & 0.1882 & 3.68 & -0.1439 & 88.7 & 90.0 & -0.0465 & 98.73 \\
\hline $\mathbf{F}$ & $2: 2$ & $8.91 \times 10^{5}$ & 0.1899 & 3.65 & -0.1455 & 90.6 & 88.3 & -0.0425 & 98.46 \\
\hline G & $3: 0.5$ & $9.49 \times 10^{5}$ & 0.1889 & 3.67 & -0.1438 & 91.0 & 91.8 & -0.0418 & 98.35 \\
\hline $\mathbf{H}$ & $3: 1$ & $1.16 \times 10^{6}$ & 0.1921 & 3.61 & -0.1352 & 92.3 & 92.8 & -0.0479 & 99.05 \\
\hline I & $3: 2$ & $9.52 \times 10^{5}$ & 0.1931 & 3.59 & -0.1610 & 91.5 & 92.2 & -0.0419 & 98.14 \\
\hline $\mathbf{J}$ (control) & 0:0 & $1.31 \times 10^{4}$ & 0.0998 & 6.95 & -0.0624 & - & - & -0.0126 & 70.81 \\
\hline
\end{tabular}

Where, $\boldsymbol{\mu}$ is specific growth rate, $\mathbf{K}_{\mathbf{d}}$ is cell deactivation rate $\left(\right.$ day $\left.^{-1}\right), \mathbf{T}_{\mathbf{d}}$ is biomass doubling time (day) and $\mathbf{k}$ is crude oil degradation rate $\left(\right.$ day $\left.^{-1}\right)$.

\subsection{Microbial growth kinetics in crude oil degradation}

Bacterial population in the artificially polluted soil enumerated before and during treatment showed increase in biomass with time in each treatment. The trend went through a gradual and rapid growth phase to a peak growth and a declining growth phase afterwards. HDB growth (Figure 1) was gradual from day 3 sequel to application of nutrient but more luxuriant between day 21 and day 35 and relatively plateaued to day 49. HDF (Figure 2) had exponential 
growths between day 7 and day 49. The luxuriant microbial growth experienced against the control showed the influence of NPK fertiliser and saw dust on the growth pattern. HDB growth rate in each treatment is as shown in Table 3.

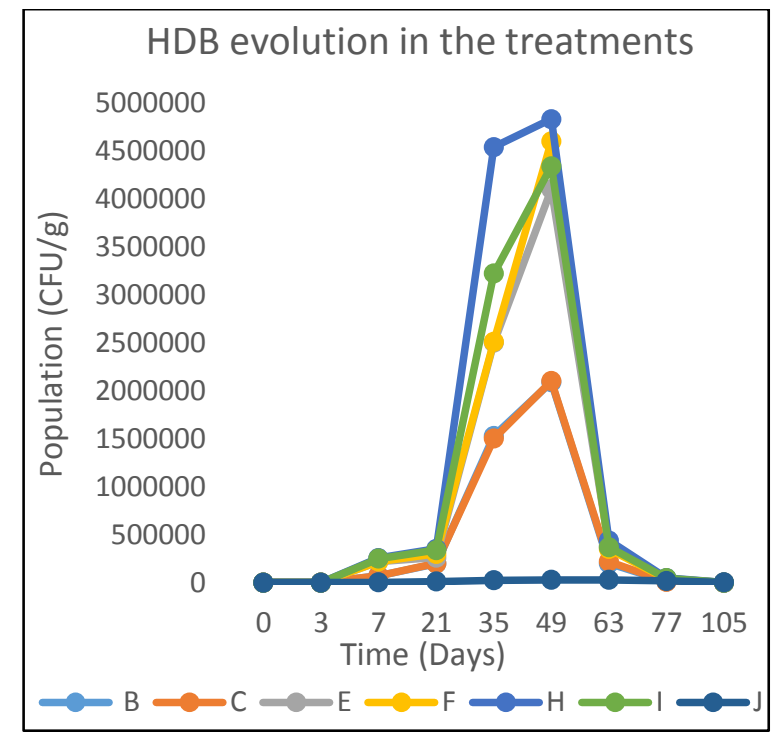

Figure 1: Hydrocarbon degrading bacteria growth profile in the treatments.

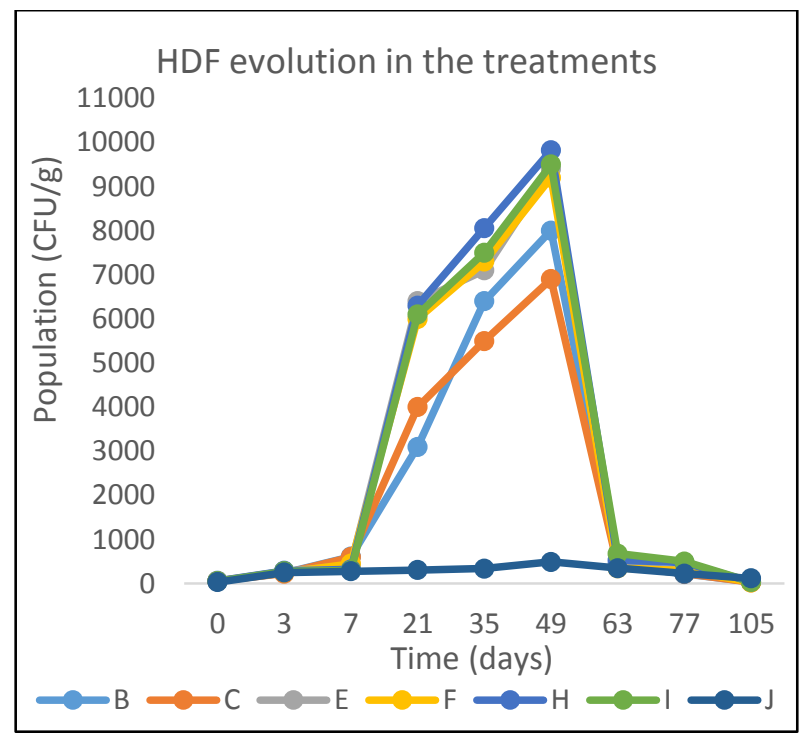

Figure 2: Hydrocarbon degrading fungi growth profile in the treatment.

In agreement with the works of [22] introduction of nutrient into the crude oil polluted medium induced the growth of microbes and synthesis of associated key enzymes for biodegradation. This translated the hitherto lag phase between day 0 and day 3 to an accelerating growth phase between day 3 and day 7 as shown in Figures 1 and 2. Exponential growth with a sustained maximum enzyme activity occurred between days 21 and 49 resulting in maximum degradation of the pollutant with a corresponding utilization of the nutrients. As depletion of the nutrient continued, the growth rate decelerated between days 49 and 63 and gradually tended to a halt as the nutrient concentration at day 105. With the nutrient concentration so depleted, biodegradation receded showing the influence of nutrient on microbial growth/activity and crude oil biodegradation.

The changes in concentrations of nitrogen and phosphorus following microbial biomass growth and crude oil degradation are shown in figures 3 and 4. Total nitrogen had an initial slow decrease between day 3 and day 7 followed by a rapid decrease between day 7 and day 63. Similarly, total phosphorus showed the same pattern. There were variable reductions in concentration of these nutrients according to the stock in each treatment. However, in treatment $(\mathrm{H})$, nitrogen utilisation at the end of the study was $92.37 \%$ and phosphorus $92.87 \%$ respectively as in Table 3. It was obvious that the higher the strength of the nutrient and amendment, the higher the concentration of both nitrogen and phosphorus in the medium and the higher the microbial population with a resultant higher treatment efficiency. 


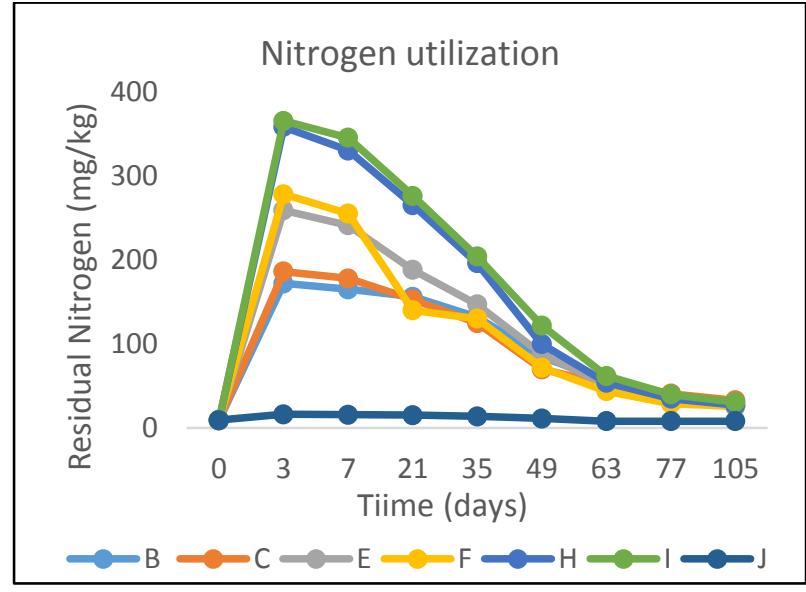

Figure 3: Nitrogen utilisation by microorganisms in the soil treated with NPK fertiliser and saw dust

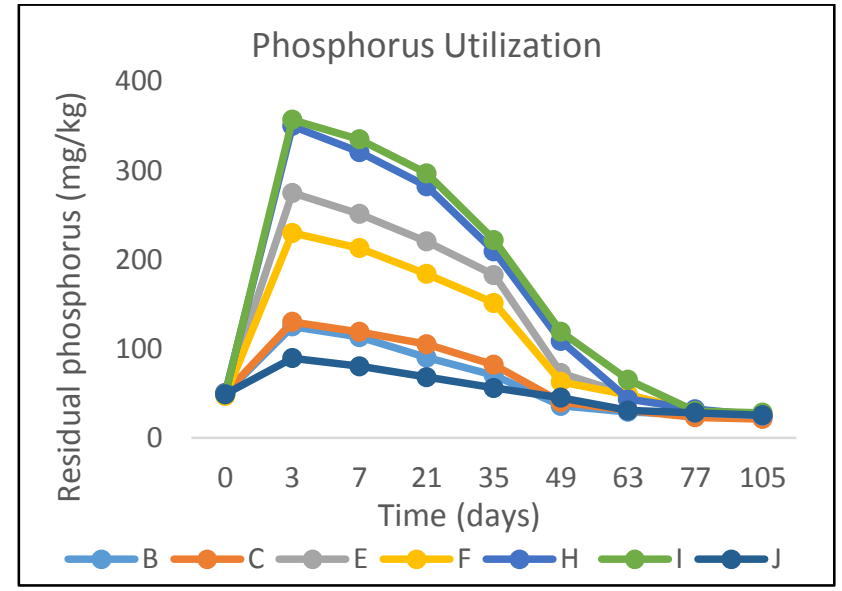

Figure 4: Phosphorus utilisation by microorganisms in the soil treated with NPK fertiliser and saw dust

Rate of degradation increased variably in all treatments after day 3 as shown in figures 5 and 6 , due to the continuous growth of microorganisms. This trend peaked on day 35 in treatment $\mathrm{H}$ and day 49 in the other treatments while the control gradually degraded to its maximum on day 63 . However, the initial TPH concentration of $11000 \mathrm{mg} / \mathrm{Kg}$ was degraded to $104 \mathrm{mg} / \mathrm{Kg}(99.05 \%)$ in treatment $(\mathrm{H})$ at the end of the study. In like manner, PAH was degraded from $28 \mathrm{mg} / \mathrm{Kg}$ to $11 \mathrm{mg} / \mathrm{Kg}(60.7 \%)$ by day 105 of the study.

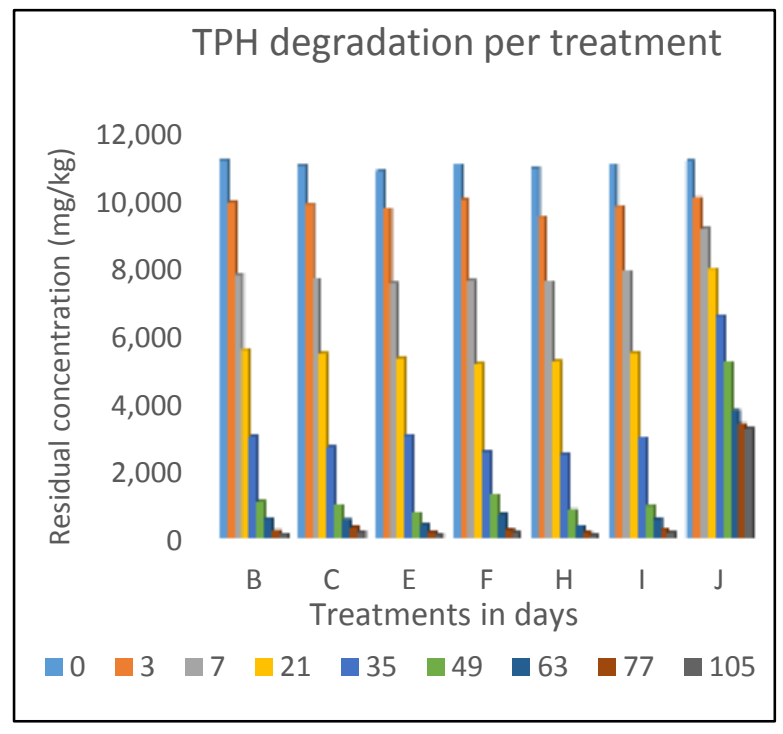

Figure 5: Residual TPH in the polluted soil following treatment with NPK fertiliser and saw dust amendment with time

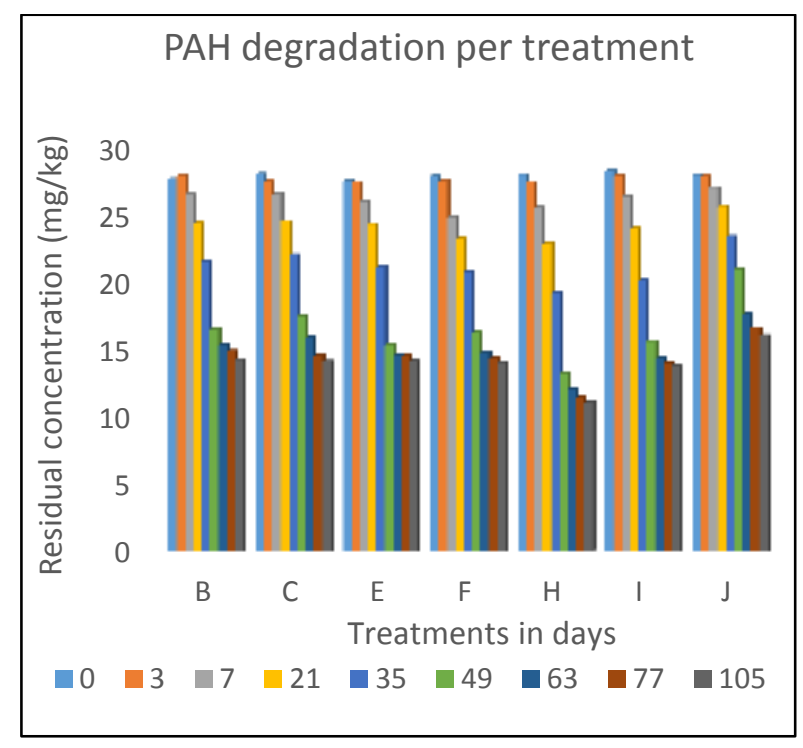

Figure 6: Residual PAH in the polluted soil following treatment with NPK fertiliser and saw dust amendment with time.
However, the

process is autocatalyic, influenced by the optimum condition of the medium such that the growth rate and biomass doubling time of microorganisms was determined with the relation,

$\operatorname{In} X=\operatorname{In} X_{o}+\mu t$

$t_{d}=\operatorname{In} 2 / \mu$ 
The loss of viability of microbial cells over time relative to earlier population resulted from nutrient exhaustion and the ensuing toxicity of the environment by acid radicals from their death. It was determined by the kinetics of cell deactivation which also followed first order as presented in the relation,

$\operatorname{In} X=\operatorname{In} X_{0}-k_{d} t$

Where; $\boldsymbol{X}_{\boldsymbol{o}}$ is initial biomass concentration, $\boldsymbol{X}$ is Biomass concentration at time t,

$\boldsymbol{t}$ is biodegradation time, $\mathbf{t}_{\mathbf{d}}$ is the biomass doubling time (d), and $\boldsymbol{\mu}$ is the specific growth rate.

The kinetics of bacterial biodegradation of hydrocarbon in the treatments is shown in Figures 7 and 8 respectively. The specific biomass growth rates $(\boldsymbol{\mu})$ increased with successive fertilizer levels of (A, B, C), (D, E, F) and (G, H, I) and also with increase in sawdust concentration within each level. This microbial growth with increase in sawdust concentration at particular fertilizer levels resulted from optimal flow of nutrient, air and comfortable surface area of the sawdust for adsorption by microbes. The growth rates were between $0.1921 /$ day and $0.1931 /$ day in the treatments. In a similar vein, biomass deactivation $\left(K_{d}\right)$ occurred at a rate between $-0.1442 /$ day and $-0.1644 /$ day in the treatments. At the growth phase, the treatments had a biomass doubling time $\left(\mathrm{T}_{\mathrm{d}}\right)$ of 3.59 days to 3.77 days indicating luxuriant growth owing to nutrient availability and favorable environment offered by saw as shown in table 3 . Treatment $\mathrm{H}$ showed the highest biomass growth rate and a high frequency of replication at the least doubling time sequel to the optimum combination of the NPK/sawdust amendment producing $99.05 \%$ restoration efficiency and a biostimulation efficiency of $28.5 \%$.

The high growth rate of hydrocarbon degrading bacteria in all the treatments is a function of the adaptation of the microorganisms to the new condition of the medium thus its proliferation with enhanced potential for degradation of the pollutant. Relating the growth rate with the concomitant restoration of the soil, the following sequence of growth rate was observed: treatment $\mathrm{H}(0.1921)>$ treatment $\mathrm{E}(0.1882)>$ treatment $\mathrm{B}(0.1840)$ corresponding to optimum soil restoration efficiencies of $99.05 \%, 98.73 \%$ and $98.70 \%$ respectively.
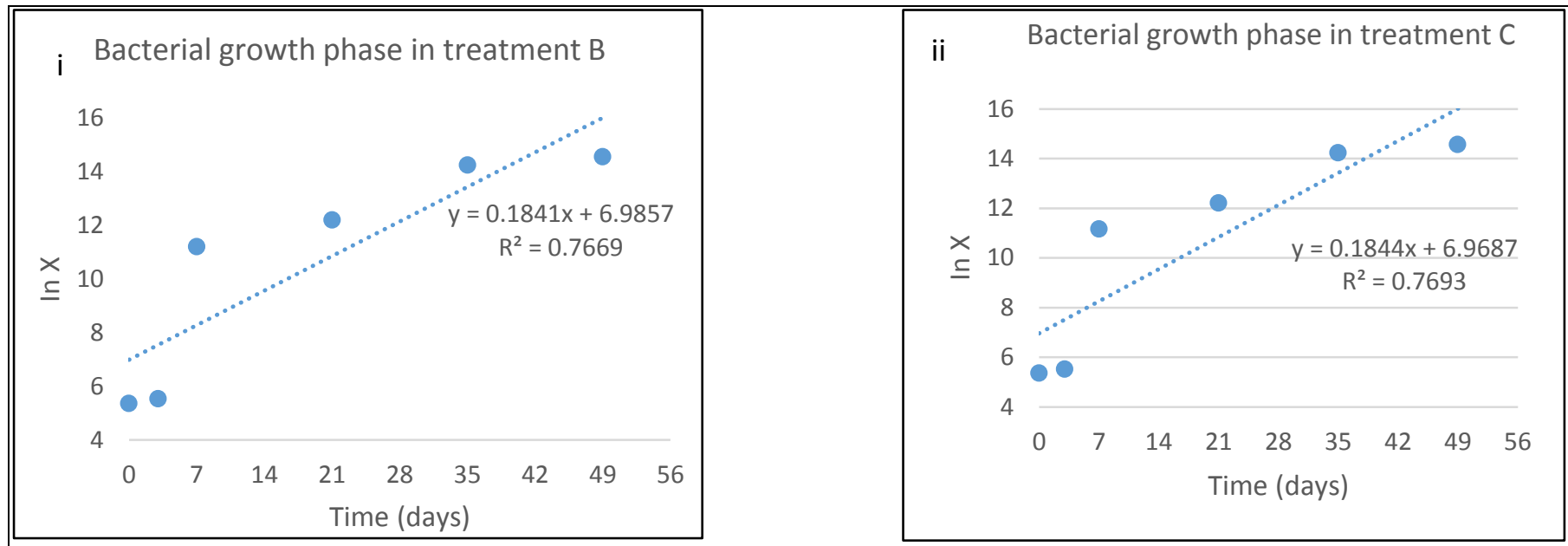
International Journal of Advances in Scientific Research and Engineering (ijasre), Vol 6 (1), January-2020

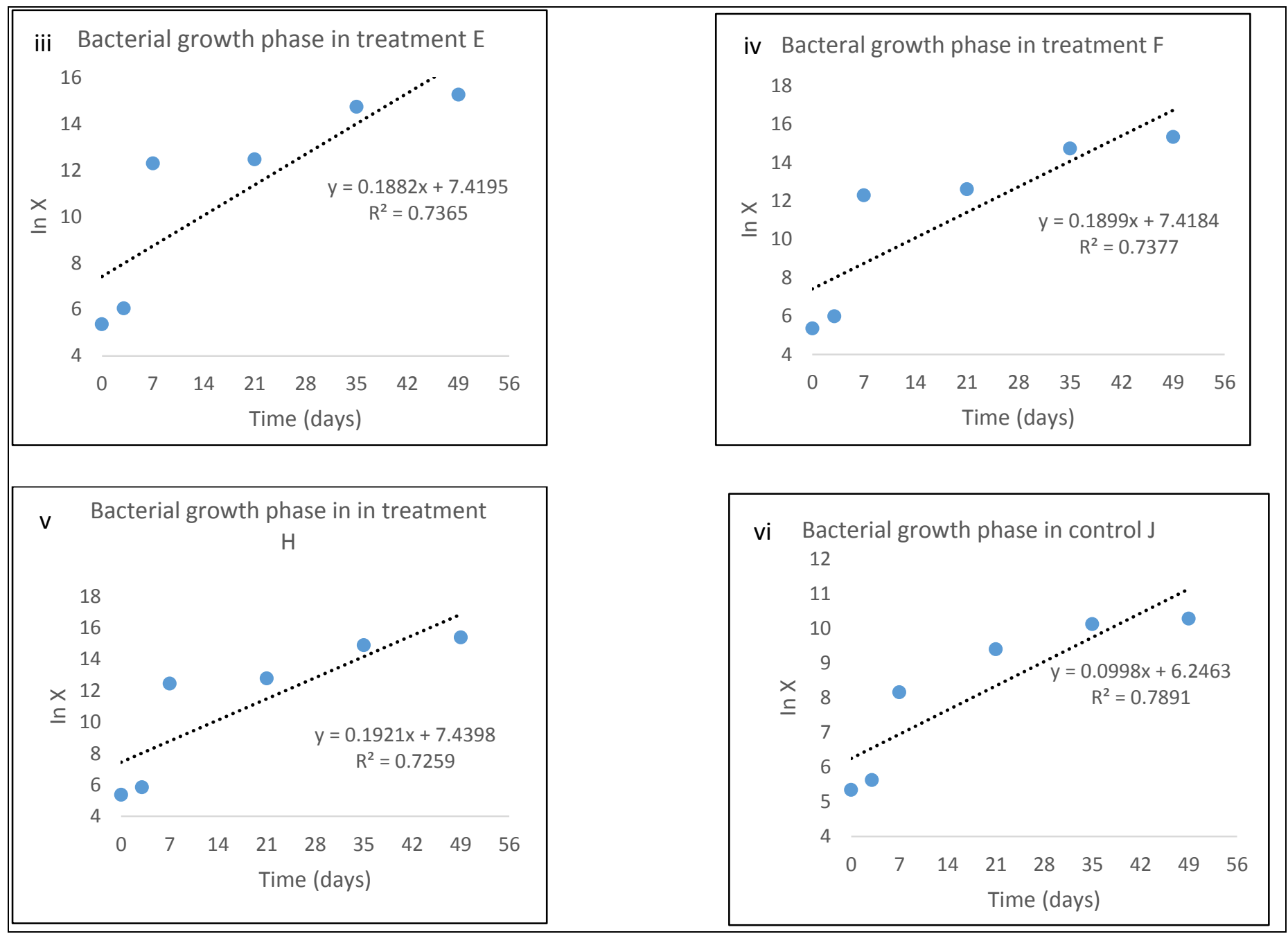

Figure 7: (i -vi) Kinetics of bacterial growth phases in soil treated with NPK fertiliser and saw dust amendment and the control $(\mathbf{J})$

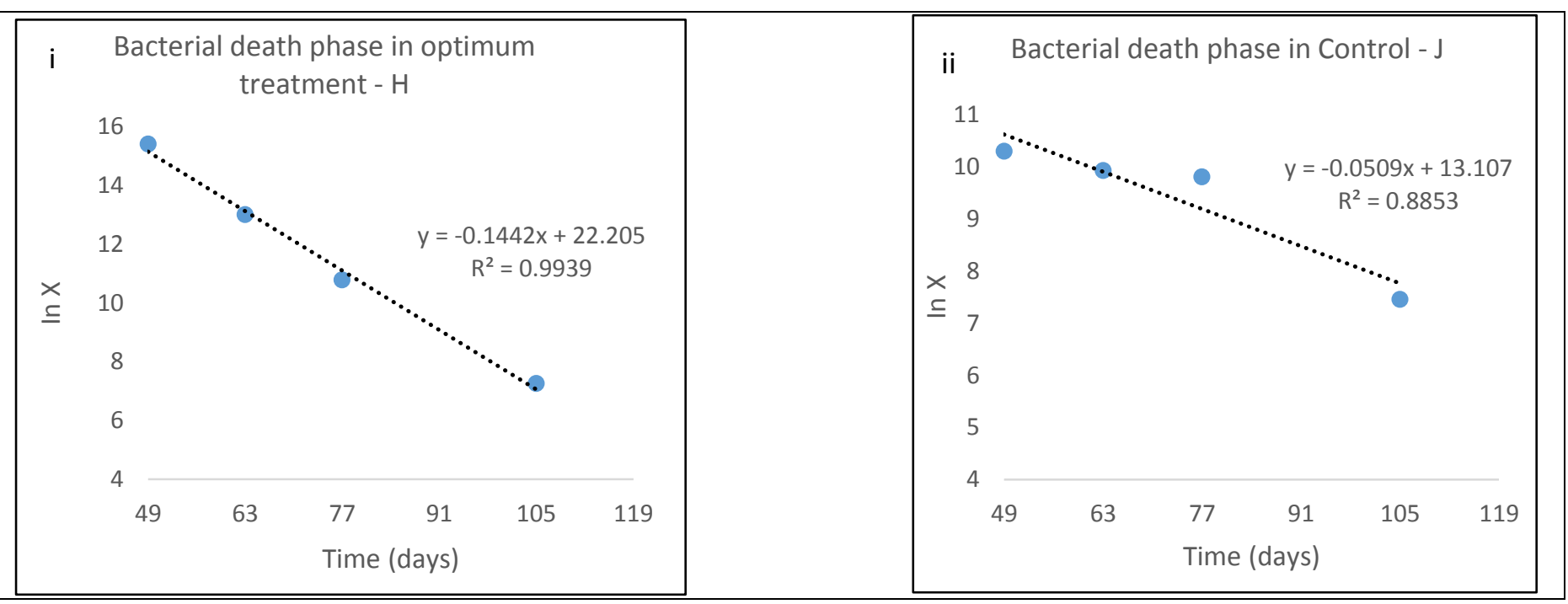

Figure 8: (i-ii) Kinetics of bacterial death phase in soil treatment with NPK fertiliser and saw dust amendment (H: optimum treatment) and control (J: natural attenuation)

Increase in nutrient concentration to a threshold of $3 \mathrm{~kg}$ of NPK fertiliser and $1 \mathrm{~kg}$ of sawdust in the different batches positively and optimally influenced the growth rate of the organisms. The higher the growth rate, the higher the 
microbial population and the higher the degradation rate of the pollutant with a resultant speedy restoration of the soil at lower half-life time. Integration of sawdust in biostimulation aptly satisfies the waste-to-wealth concept of waste management, utilising locally available waste matter to achieve remediation goal with no ecological consequence or effect on resources management.

\subsection{CONCLUSION AND RECOMMENDATIONS}

The evolution of microorganisms in the process of degradation of crude oil in polluted tropical soil was evaluated. Treatment with NPK fertilizer and saw dust amendment efficaciously provided nutrient and conducive medium suitable for luxuriant growth of crude oil degrading microorganisms. A microbial growth rate of 0.1921per day resulted in 99\% degradation efficiency of soil TPH at a biodegradation rate of $-0.0479 /$ day and degradation half-life of 14.47days. Optimum application of the treatment factors enhanced a million-fold microbial population proliferation for crude oil biodegradation. Mycobacterium spp., and Corynebacterium spp., as well as Acremonium spp., and Fusarium spp., which were hitherto not significant, showed predominant presence following NPK-saw dust amendment. The functionality of the polluted soil was restored within four months. This technique should therefore be adapted for wider application on crude oil polluted soil. Further research should be conducted using this template on other types of soil and also in non-tropical climate.

\section{ACKNOWLEDGMENT}

This research was not funded by any agency in the public, commercial or not for profit sectors.

\section{CONFLICT OF INTEREST}

There is no conflict of interest.

\section{REFERENCES}

1. Juwarkar Asha A, Singh Sanjeev K, Mudhoo A (2010): A Comprehensive Overview of Elements in Bioremediation. (Environmental Science Biotechnology 9: 215-288).

2. Atlas Ronald M (1981): Microbial degradation of petroleum hydrocarbon: an environmental perspective (Microb. (45): 180-209)

3. Serrano A, Tejada M, Gallego M, Gonzalez J.L (2009): Evaluation of soil biological activity after a diesel oil spill (Science of the total environment 407:4056-4061).

4. Onifade A.K, Abubakar F.A, Ekundayo F.O (2007): Bioremediation of crude oil polluted soil in the Niger delta area of Nigeria using enhanced natural attenuation (Journal of applied science (series 2).

5. Chikere C.B, Okpokwasili G.C, Chikere B.O (2009): Bacterial diversity in a tropical crude oil polluted soil undergoing bioremediation (African journal of biotechnology, 8(2):2535-2540).

6. Aislabie J, Saul DJ, Foght JM (2006): Bioremediation of hydrocarbon contaminated polar soil (Extremophiles 10:171-179)

7. Chang W; Dyen M; Spagnuolo Lou; Simon P; White L; Goshal S (2010): Biodegradation of semi and nonvolatile hydrocarbon in aged contaminated soil from a subarctic site: Laboratory Pilot-scale Experiments at Site Temperatures (Chemosphere 80 (3) :319-26.

8. Kauppi Sari; Sinkkonen Aki; Romantschuk Martin (2011): Enhancing Bioremediation of Diesel-fuelcontaminated Soil in a Boreal Climate; Comparison of Biostimulation and Bioaugmentation. (International Biodeterioration and Biodegradation 65 (2): 359-368)

9. Sanscartier, D., Laing, T., Reimer, K., Zeeb B., 2009. Bioremediation of Weathered Petroleum Hydrocarbon Soil Contamination in the Canadian High Arctic: Laboratory and Field Studies.

10. Neebee E, Nkwocha E E, Oguzie E E (2019): Effectiveness of NPK Fertilizer-Saw Dust Amendment on Biodegradation of Crude Oil in Polluted Soil (International journal of advances in scientific research and engineering 5(5):56-67.

11. Infante C, Morales E, Ehrann E.U, Hernandez I, Leon N (2010): Hydrocarbon bioremediation and phyto remediation in tropical soil - Venezuelan study case (Trends in bioremediation and phyto remediation, 42945 
12. Namkoong W, Hwang E, Park J, Choi J (2002): Bioremediation of diesel contaminated soil with composting (Environmental pollution 119 (1): 23-31)

13. Adekunle, Iheoma M. (2011). Bioremediation of Soils Contaminated with Nigerian Petroleum Products Using Composted Municipal Wastes. Bioremediation Journal 15(4): 230-241.Namkoong W, Hwang E, Park J, Choi J (2002): Bioremediation of diesel contaminated soil with composting (Environmental pollution 119 (1): 23-31)

14. Heitzer A, Scholz R.W (1994): Monitoring and evaluating the efficacy of bioremediation - a conceptual framework (A working paper on the chair of environmental science, natural and social science interface, Swiss Federal institute of Technology, Zurich.

15. Williams S D; Ladd D E; Farmer J J (2006): Fate and transport of petroleum hydrocarbon in soils and ground water at big South Fork national river and recreational area, Tennessee and Kentucky, 2002 - 2003 (Scientific investigations report, US department of interior and US Geological survey).

16. Nilanjana D and Chandran P (2011): Microbial Degradation of Petroleum Hydrocarbon Contaminants: An Overview. (Biotechnology Research International 2011, Article ID 941810).

17. Jain P.K, Gupta V.K, Lowry M, Jaroli D.P, Chauhan U.K (2011): Bioremediation of petroleum oil contaminated soil and water. (Research journal of environmental toxicology 5:1-26.

18. Megharaj Mallavarapu; Balasubramunian Rakrihnan; kadiyala Venkateswarlu; Nambrattu Sethunathan; Ravi Naidu (2011): Bioremediation approaches for organic pollutants: A critical perspective (Journal of environment international 37:1362-1375).

19. Cerqueira Vanessa S; Hollenbach Emmanuel B; Maboni Franciele; Vainstein Marilene; Camargo Flavio; Do Carmo Maria; Peralba R; Bento Fatima (2011): Biodegradation Potential of Oily Sludge by Pure and Mixed Bacterial Cultures. Bioresource Technology 102: 11003-11010.

20. Sayara Tahseen; Borràs Eduard; Caminal Gloria; Sarrà Montserrat; Sánchez Antoni (2011): Bioremediation of PAHs-contaminated Soil through Composting: Influence of Bioaugmentation and Biostimulation on Contaminant Biodegradation. International Biodeterioration \& Biodegradation 65(6): 859-865

21. Chikere C.B, Okpokwasili G.C, Chikere B.O (2011): Monitoring of microbial hydrocarbon remediation in the soil (Journal of biotechnology 1(3):117-138).

22. Chorom M; Sharifi H.S; Motamedi H (2010): Bioremediation of a crude oil polluted soil by application of fertilizers. (Iran journal of environmental health science \& engineering 7(4):319-326). 